\title{
THE PRESENT TENSE WITH FUTURE MEANING IN THE ACCUSATIVE AND INFINITIVE CONSTRUCTION IN PLAUTUS AND TERENCE $\{1\}$
}

\author{
By WolfGang David Cirilo de Melo \\ University of Oxford
}

\begin{abstract}
In the accusative and infinitive construction in Archaic Latin, both present and future tense infinitives can be found if there is future meaning; semantic differences cannot be detected. Various scholars have tried to show that the present infinitive is colloquial here or that the alternation between the two tenses has to do with semantic differences in the governing verbs. However, on closer examination of the data such theories cannot be upheld. In this paper, I shall demonstrate that the present infinitive is restricted to telic events. Moreover, it is particularly frequent if the subjects of the superordinate and subordinate verbs are identical. The present infinitive of the verb 'to give' occurs more often than present infinitives of other verbs. Finally, we can observe how such present infinitives become less frequent if we compare Plautus and Terence.
\end{abstract}

\section{INTRODUCTION}

The accusative and infinitive or accusatiuus cum infinitiuo (henceforth AcI) is one of the most interesting constructions in Latin. Of the many problems associated with it, only a few can be mentioned here: it is remarkable that the subject of the infinitive is in the accusative, and it is not immediately obvious why this should be the case; moreover, it is intriguing that other 
ancient Indo-European languages have AcIs, even though it is generally said that IndoEuropean had no infinitives as such; similarly, it is not always clear to what extent AcIs in modern European languages were influenced by the Latin construction. All of these questions have been discussed extensively elsewhere. $\{2\}$ In this article, I shall restrict myself to one problem that has not been given so much attention, namely the tenses selected by the infinitive if there is future reference.

In Latin, infinitives, like finite verbs, have tense. If a finite clause is turned into an AcI, the tense of the infinitive is determined by the tense of the finite verb: past tenses indicating anteriority are rendered by the perfect infinitive, the present tense is turned into the present infinitive, and future tenses are reflected by the future infinitive. $\{3\}$ In Classical Latin, these rules are relatively strict, so there is normally agreement between tense and time reference: the perfect infinitive stands for anterior events, the present infinitive for simultaneous ones, and the future infinitive for posterior ones. These rules are uncontroversial, and if this article were about Classical Latin, it would end here.

In Archaic Latin, the perfect infinitive is also used for anterior events and the present can be used for simultaneous ones. This is no different from Classical Latin and also entirely uncontroversial. However, there is one area where the rules for the tenses of the infinitives diverge. Archaic Latin seems to allow present tense and future tense infinitives if there is future reference; in my first example, both can be seen:

(1) (A slave urges his master to pay an obstinate money-lender.)

slave: dic te daturum, ut abeat. master: egon dicam dare?

'slave: say that you will give (future infinitive), so that he goes away. master: I am to say that I give (present infinitive)?' (Plaut. Most. 633) 
There are two AcIs with future reference dependent on the same verb dicere; but the first AcI has a future tense infinitive with subject accusative, and the second has a present tense form without accusative. $\{4\}$ Neither here nor in the other examples can I detect purely temporal differences, for instance of the kind that the present infinitive refers to the near future and the future infinitive to a more distant time. To some extent, (1) resembles conjunction reduction in Sanskrit; $\{5\}$ it could be argued that the future infinitive daturum unambiguously establishes future reference so that in the master's reply an unmarked present infinitive is sufficient. However, in most cases no future infinitive precedes, and it is merely knowledge of the situation that enables us to tell whether a present infinitive has present or future reference.

To put it more generally, future infinitives always have future reference in Archaic Latin, just as in Classical Latin, but present infinitives can be used for either the present or the future. In other words, the present infinitive has a greater sphere of usage in Archaic than in Classical Latin. The question I am interested in is whether in Archaic Latin the alternation between future infinitives and present infinitives with future meaning is random or not.

Several scholars claim that there is a rationale behind it. Kühner \& Stegmann (1962: 690) believe that the present infinitive instead of the future form is a colloquialism. Admittedly, in the classical period and later on the present infinitive with future meaning did survive mainly as an archaism (Kalb 1888: 43-6) or as a feature of non-literary language (Adams 1977: 51). However, for Archaic Latin it seems less likely that we are dealing with a colloquialism because the construction occurs in tragedy and epic as well; although both genres also drew on the colloquial register from time to time, this happened considerably less frequently than in comedy. $\{6\}$ Often it is also said that the present indicative with future meaning is colloquial (Hofmann \& Szantyr 1965: 307-8), but it is unclear whether such statements can be upheld for Archaic Latin, where this usage seems to be determined by lexical factors and collocations (Sjögren 1906: 71). Pinkster (1998: 66-8) looks at examples 
from Plautus and Terence and remarks that while the present can refer to events after the moment of speech, it is not used as a substitute for the future because present and future occur under different circumstances; the present is for instance preferred in expressions of the type 'I shall be back in a second'. This points to a difference between present and future indicatives that has to do with meaning rather than register. The use of present indicatives with future reference continues right through Latin and Romance, and the fact that it is not necessarily colloquial in Plautus and Terence does not mean that the construction did not come to be associated with lower register later on. However, even if it should be a colloquialism as early as Plautus, there need not be a connection with the present infinitive with future meaning since the present indicative replaces a future of the same stem, while the present infinitive substitutes for a future form belonging to a different stem.

Other scholars think that the semantics of the governing verb has some influence on whether an AcI with future meaning contains a present or a future infinitive. Bennett (1910: 426) states that the present tense infinitive with future meaning is common 'especially with verbs whose meaning involves a reference to future time, as verbs of hoping, promising, swearing, vowing, threatening, etc.'. Hofmann \& Szantyr (1965: 357-8) and Sjögren (1906: 57-8) do not offer an explanation why some verbs should be more prone than others to take present infinitives with future meaning, but claim that such infinitives can be found most frequently after verbs of saying and sperare 'hope', while after censere 'think', credere 'believe', putare 'believe', and scire 'know' this usage is rare.

Bennett's idea seems untenable. In my corpus, which consists of Plautus (ca 254-184 BC) and Terence (ca 185-159 BC), confidere 'trust' has no infinitives with present reference, so it should be possible to use present and future infinitives indiscriminately; but only the future infinitives are used (17 times). $\{7\}$ Dicere 'say', on the other hand, has 247 AcIs with present and future infinitives. 164 of them, that is $66.40 \%$, are infinitives with present reference; all of them are present infinitives. 83 infinitives have future reference, and since 
there are so many present infinitives with present meaning we might expect that only future infinitives are used if there is future reference so as to avoid confusion. However, this is not true, as 26 out of these 83 infinitives are present infinitives.

I cannot go into the theories of Hofmann \& Szantyr or Sjögren in detail, but it seems that the present infinitive with future reference is indeed more easily permitted after verbs of speech and sperare 'hope' than after verbs of thinking like credere 'believe' or confidere 'trust'. However, the patterns are not as clear-cut as one might wish and there is no semantic reason why things should be like this. As I shall argue below, it depends mainly on the meaning of the AcI which tenses are used. The true reason behind the patterns in Hofmann \& Szantyr or Sjögren is that some verbs are more likely than others to take AcIs with a certain meaning.

The voice of the infinitive is another factor that might matter. Adams (1977: 51) notes the 'lack of currency of the future passive infinitive' in non-standard texts, and similar patterns can be detected in Plautus and Terence. But since passive infinitives, regardless of whether they are in the future or the present tense, never even make up $11 \%$ of the total of infinitives in Plautus and Terence, we should not overestimate this factor.

So is the alternation between the tenses random? Or what determines it? In order to find out, I examined all the AcIs in Plautus and Terence that depend on the following verbs listed in Bennett (1910: 426-7): adiuro 'I swear', aio 'I say', arbitror 'I have an opinion', audio 'I hear', autumo 'I say', censeo 'I think', denego 'I deny', dico 'I say', interminor 'I threaten', iuro 'I swear' (with ius iurandum do 'I give an oath'), minor 'I threaten', nego 'I deny', polliceor 'I promise', promitto 'I promise', repromitto 'I promise in return', scio 'I know', spero 'I hope', and иоиеo 'I vow'. $\{8\}$ I also added confido 'I trust' and credo 'I believe' to the list, which increases the number of superordinate verbs to twenty. $\{9\}$ In this sample, I identified four factors that matter for the alternation between the tenses. I shall now discuss them in order of importance: the meaning of the infinitives in combination with their 
complements exerts the greatest influence on tense choice. Another factor that cannot be neglected is whether the subject of the infinitive is identical with that of the superordinate verb. For reasons explained below, dare 'give' is more prone to have present infinitives with future meaning than other verbs. And finally, there is a diachronic decline of the present infinitive with future meaning.

\section{THE FOUR FACTORS}

\subsection{Telicity}

It is a strange fact that scholars examining the use of present infinitives with future reference have hardly paid any attention to the semantics of the infinitives themselves. However, it is the semantics of the infinitives - together with their complements - which will turn out to be the single most important factor determining the choice between future infinitives and present infinitives with future reference.

The distinction which will be crucial is that between telic and atelic events. $\{10\}$ By 'events' I mean verbs in combination with their complements. Two examples will make the difference between telic and atelic clearer:

(2) Mark is running home.

(3) Mark is running. 
Running home in (2) is telic because it has a clearly definable end: once Mark has reached home, he has completed the activity I was talking about. He may continue running afterwards, but that is irrelevant here. By contrast, if there is no surrounding context indicating the opposite, running in (3) is atelic because it does not have such an endpoint. Of course no one would assume that Mark will be running for ever, so there will be an end of some sort, but the statement is true as soon as Mark has started to run - he does not have to complete any special task.

The easiest way to find out whether a verb with its complements is telic or not is the 'interruption test':

(4) Mark stopped running home. $\rightarrow$ he has not (yet) run home.

(5) Mark stopped running. $\rightarrow$ he has been running.

In (4) I am interrupting a telic event. This entails that it has not reached its endpoint and that the statement Mark has run home would be false. In (5) I am interrupting an atelic event. Even if Mark does not continue his run afterwards, the statement Mark has been running is true.

The distinction between telic and atelic events in Latin and English can sometimes be problematic, but on the whole the number of cases where a decision between telic and atelic is difficult is not too great. (6) and (7) are Latin examples of this distinction:

(6) (A young man wants to take a pimp to court.)

young man: ambula in ius. pimp: non eo.

'young man: go to court. pimp: I'm not going.' (Plaut. Curc. 621) 
(7) (A pimp is telling a slave about his bad health.)

pimp: lien dierectust. slave: ambula, id lieni optumumst.

'pimp: my spleen is in a terrible state. slave: go for a walk, that's best for your spleen.'

(Plaut. Curc. 244)

In (6), ambula has an endpoint, namely the court, and so it is telic. In other instances, the endpoint is not stated explicitly, but has to be inferred from the context. Such events nevertheless count as telic. In (7), ambula means 'go for a walk' and has no inherent endpoint, even though the pimp is not supposed to go on walking for ever. Of course the pimp's walk is not intended as an aimless activity, but as a means of getting well. However, the fact that the walk has a purpose does not mean that its endpoint is specified explicitly or implicitly; if the pimp's activity were interrupted, he could still truthfully say that he has walked. On the other hand, if the pimp's walk to the court were interrupted in (6), he would have to admit that he has not yet walked to the court.

It can be shown that AcIs with present infinitives and present reference are by and large atelic, while AcIs with future reference are more frequently telic than atelic, regardless of whether the future or the present tense is used. Table 1 presents the relevant data after the twenty superordinate verbs in Plautus and Terence.

Table 1 around here

AcIs with present reference are atelic in almost $90 \%$ of all the cases, while AcIs with future reference are telic in around $64 \%$ of all the tokens. $\{11\}$ At first sight this finding may look surprising, but it can be explained relatively easily if one considers what situations AcIs with present and with future reference normally describe. At least in my corpus, AcIs with present reference are predominantly used not to talk about activities, but about states and 
ongoing situations (be here, be tired, be angry etc); unlike actions, states and situations are most frequently atelic. AcIs with future reference, on the other hand, more often than not refer to actions, which are prototypically telic.

If we now look at the AcIs with future reference in more detail, we can find all combinations of telicity and tense. There are telic future infinitives (8), atelic future infinitives (9), telic present infinitives with future reference (10), and atelic present infinitives with future reference (11):

(8) (Phaedromus is waiting for Curculio.)

confido parasitum hodie aduenturum

cum argento ad me.

'I'm sure my hanger-on will arrive at my place today with money.' (Plaut. Curc. 143-

4)

(9) (Agorastocles is confident that he will achieve his goals.)

egoquidem meos amores mecum confido fore.

'I'm sure my darling will be with me.' (Plaut. Poen. 1165)

(10) (Trachalio is complaining about a pimp.)

sciui lenonem facere ego hoc quod fecit; saepe dixi.

'I knew the pimp would do what he did; I often said so.' (Plaut. Rud. 376)

(11) (Daemones is annoyed by Trachalio's prolix entreaty.)

at ego te per crura et talos tergumque optestor tuom,

ut tibi ulmeam uberem esse speres uirgidemiam

et tibi euenturam hoc anno uberem messem mali, 
ut mi istuc dicas negoti quid sit quod tumultues.

'but I beseech you by your shins, your ankles and your back, as you're hoping to have a rich harvest of elm rods, and as you're hoping to get a rich gathering of blows this year, that you tell me what this business of yours is because of which you're creating such an uproar.' (Plaut. Rud. 635-8)

In (8) and (9) there are future infinitives. Aduenturum in (8) is telic because there is a clear endpoint; as soon as Curculio arrives, this endpoint has been reached. Fore in (9) describes a situation without a clearly definable end; in fact, Agorastocles probably does not expect there to be an end at all. (10) and (11) both contain present infinitives with future reference, and in (11) this present infinitive is combined with a future infinitive proper, euenturam. The present infinitive in (10) is telic. Trachalio is referring to a specific deed, and such a deed must have an endpoint. Esse in (11), however, is atelic. The 'harvest' will of course be over after some time, but this endpoint is not specified $\{12\}$ and is irrelevant here.

These examples show that several combinations of tense and telicity are possible with future meaning. However, not all of them are equally frequent, and we can observe a remarkable pattern of distribution:

Table 2 around here

Table 2 shows very clearly that future infinitives are used regardless of whether the event is telic or not, whereas present infinitives with future reference are more or less restricted to telic AcIs. $\{13\}$ There are only six exceptions. One of them is the infinitive licere 'be allowed' in Ter. Haut. 103, a verb which does not normally have a future infinitive. Other than that, we find four tokens of esse 'be' (Plaut. Persa 260, Plaut. Rud. 636 (example (11) above), Plaut. Truc. 936, and Ter. Eun. 275) and one of ferre 'bear' (Plaut. Asin. 699) with 
future reference; since both of these are frequent verbs, they could have preserved earlier usages better. Among the telic events, the present infinitive with future meaning is quite frequent in Plautus and Terence: 74 out of 185 telic infinitives with future reference are in the present tense, which amounts to $40 \%$.

How did this pattern come about? Infinitives are relatively recent innovations in the Indo-European languages, $\{14\}$ and verbal nouns were probably not yet fully grammaticalized as infinitives in Proto-Italic $\{15\}$ - note that the infinitives of Oscan and Umbrian have different endings from the Latin ones. But while the present infinitive endings of Latin can be given sensible etymologies by comparing them with case forms of cognate languages, $\{16\}$ the future infinitives have no such analogues. The future infinitives seem to have been created within Latin itself, after the present infinitives. $\{17\}$ It is a reasonable assumption that before the creation of future infinitives the 'present' infinitive was a non-past infinitive; in other words, the present infinitive could be used for both present and future events. Incidentally, the same is still true of the 'present' subjunctive in Archaic and Classical Latin, which is really a non-past subjunctive. After the advent of future infinitives, the present infinitive was being more and more restricted to events with present reference.

This restriction process was of course not completed overnight. But why did it take place in the way it did? Why did the future infinitives replace the atelic present infinitives with future reference almost completely, while this process is anything but complete among the telic events? Here it might be helpful to look at the data from table 1 again. There is a robust pattern of distribution: of the 1011 infinitives, 270 are telic and 741 are atelic. Of the 270 telic infinitives, only $31.48 \%$ (85 tokens) have present reference, while $68.52 \%$ (185 tokens) have future reference (future or present tense). Of the 741 atelic infinitives, $85.96 \%$ (637 tokens) have present reference, but only 14.04\% (104 tokens) have future reference (future or present tense). Thus, situations with endpoints are somewhat more likely to have future reference than those without, whereas situations without endpoints are far more likely 
to have present reference than those with endpoints. In a stage of pre-Latin where there were no future infinitives yet, there must have been the frequency pattern presented in table 3 .

Table 3 around here

When future infinitives were introduced, they naturally replaced the very rare atelic present infinitives with future reference before the frequent telic present infinitives with future reference. In Archaic Latin, this first process is almost completed, while the second process, the replacement of telic present infinitives with future reference by future infinitives proper, is still in progress.

The synchronic and diachronic patterns are clear, and the replacement processes have to do with the relative frequencies of combinations of telicity and time reference. But why are there such patterns of frequency? What is the ultimate semantic reason behind them?

Perhaps a few English examples can help to clarify why these patterns exist; one might overhear all of the following sentences in an office:

(12) an employee has worked hard: I think the boss is writing George a cheque.

(13) an employee has worked hard: I think the boss is going to write George a cheque.

(14) the work is tedious: I think John is dreaming about his holidays.

(15) the work is tedious: I think John is going to dream about his holidays.

In these situational contexts, write a cheque is telic, whereas dream is atelic. In (12) the boss may actually be in the process of writing the cheque, but it is equally possible that he 
has not yet started. If he has not yet started, he has probably taken out his cheque book or given some other indication that he is going to write the cheque, while in (13) he is less likely to have done so. However, in many contexts the two sentences can be used interchangeably; the boss has written a cheque will only be true in the future. (14) and (15), on the other hand, can never be employed in the same contexts. In (14) John is already dreaming, while in (15) he has not yet started. John has dreamt about his holidays follows from (14), but not from $(15)$.

The reason for the difference in behaviour between telic and atelic verbs (with complements) is that only telic ones like write a cheque entail that there is an endpoint, and this endpoint can never be exactly simultaneous with the superordinate verb. Thus, when I am asserting that $I$ think the boss is writing a cheque, I am merely saying that the process leading to a valid cheque has begun, but not that the cheque is already valid. Similarly, in I think the boss is going to write a cheque the cheque cannot be cashed in yet.

It is only natural that when future infinitives in -urum (esse) were created, they were first used for atelic verbs because here the difference between simultaneity and posteriority is much clearer and much more important. The expansion of the new morphology to telic verbs belongs to a period when it was already obligatory among the atelic ones. We can still see the variation among telic verbs in (1) above: the verb 'give' is telic, and so we find a future infinitive in one AcI, but a present infinitive with future reference in the other. $\{18\}$

\subsection{The subject of the infinitive}

Apart from telicity, there is another important factor which has not been considered by those looking at the tense usage in AcIs: sometimes the subject of the AcI is identical with that of the superordinate verb, and sometimes it is not. Does this correlate with the choice between 
future infinitive and present infinitive with future reference? All four combinations are attested:

(16) (Aeschinus promised to marry Pamphila.) sine hac iurabat se unum numquam uicturum diem. 'he swore that he would never live a single day without her.' (Ter. Ad. 332)

(17) (Davus is encouraging Simo.) id spero adiuturos deos. 'I hope the gods will help us in this.' (Ter. Andr. 522)

(18) (Chremes is suspicious of Pythias' intentions; he believes that she is keen on a piece of land he owns.)

sperat se a me auellere.

'she hopes she will tear it away from me.' (Ter. Eun. 520)

(19) (Geta is telling Antipho that his father and uncle are willing to accept his wife.) ait uterque tibi potestatem eius adhibendae dari. 'each of them says that you would be given permission to have her as your wife.' (Ter. Phorm. 880)

In the first two examples there are future infinitives, while in the other two there are present infinitives with future meaning. In the first example of each pair, the subject of the superordinate verb is identical with that of the infinitive; the subject accusatives are reflexive pronouns. In the second example of each pair, the subjects are different; the subject accusatives are noun phrases. However, the fact that all combinations are attested does not 
mean that all of them are equally frequent. I shall again look at the AcIs dependent on the twenty superordinate verbs in Plautus and Terence. Table 4 demonstrates that some combinations are preferred over others:

Table 4 around here

Table 4 shows very clearly that the present infinitive with future reference is in proportion much more frequent if the AcI and the superordinate verb have the same subject than if there is a different subject. $\{19\}$ However, this is not an absolute restriction. There are a number of AcIs in which the subjects do not agree, but which nevertheless have the present tense with future reference. By contrast, the restriction of the present tense with future reference to telic AcIs is almost without exceptions.

How can this second restriction be explained? Givón (2001: 50) argues that crosslinguistically two clauses tend to be more closely connected with each other syntactically if they share syntactic constituents than is otherwise the case. The more tightly a subordinate clause is connected with a main clause, the more likely it is to be non-finite, and the more likely it is to allow fewer tense distinctions. This phenomenon is of course also known from Latin: we say uolo ut des with a finite $u t$-clause because the subject of uelle is different from that of dare, but we say uolo dare with a plain infinitive when the two subjects are the same. So it is perhaps not surprising that the distinction between present and future infinitive is more regularly made if the subjects of the superordinate verb and of the infinitive differ, and that there is a strong tendency to use only the present infinitive if the two subjects are identical.

\subsection{The infinitive dare 'to give'}


There is one phenomenon that cannot go unnoticed: among the present infinitives with future reference, dare 'to give' is especially frequent. This was also observed by Sjögren (1906: 57 and 59), who says that among the 50 present infinitives with future reference in Plautus there are 18 tokens of dare. However, Sjögren does not tell us if daturum is equally frequent among the future infinitives, in which case there would be nothing special about this verb. Here are some examples of what is attested:

(20) (Demaenetus has promised to help his slaves.)

dixit sese operam promissam dare.

'he said he would give us the support he promised.' (Plaut. Asin. 366)

(21) (Lysiteles asks Charmides for permission to marry his daughter.) istac lege filiam tuam sponden mi uxorem dari?

'do you promise that your daughter will be given to me as my wife on those terms?'

(Plaut. Trin. 1162)

(22) (Chrysalus is reading out what his young master's letter says about him.) atque id pollicetur se daturum aurum mihi. 'and he promises he will give this gold to me.' (Plaut. Bacch. 742)

(23) (A priestess told Ampelisca that she should ask the neighbours for water.) nam extemplo, si uerbis suis peterem, daturos dixit. 'for she said they would give it immediately if I asked in her name.' (Plaut. Rud. 405)

(20) and (21) show present infinitives with future meaning, whereas (22) and (23) contain future infinitives proper. In (20) and (22) the reflexive pronouns indicate that the 
subjects of the superordinate verbs are identical with the subjects of the infinitives. In (21) and (23), the subjects are different; in (23), the subject of the infinitive is not expressed by a noun or a pronoun, but can be recovered from the ending of the future participle.

When we examine this verb, all the future, but not all the present forms of dare are important. Every future form has to be counted because the future infinitive can only be used in AcIs where other tense forms - with other temporal meanings - can be used as well. The present infinitive, on the other hand, does not always contrast with other tenses and is, in fact, often the only possible tense choice. This is the case for example after soleo, where infinitives other than those of the present tense are impossible. Here, the present tense is completely irrelevant for my purposes.

If I exclude those tokens, I am left with forms of dare in AcIs after verbs of speech, thought, and emotion (the traditional categories uerba dicendi, sentiendi, and affectus), for example iuro 'I swear', censeo 'I think', and grauiter fero 'I am upset'. These AcIs can have different tenses. The data for future infinitives and present infinitives with future meaning after such verbs are displayed in table 5.

Table 5 around here

The results are clear. For the verb dare, the present infinitive with future reference is more common than the future form, regardless of whether the subject of the AcI is the same as that of the superordinate verb or not. This means that there is a marked tendency for the verb dare to express future reference through the present infinitive. For other verbs, this tendency is strong if the two subjects are the same (present infinitives make up 48.82\%), but not if the two subjects differ (present infinitives make up 11.11\%).

How can this phenomenon be explained? As the Latin future infinitive seems to be a recent innovation, it is perhaps only to be expected that some verbs should at least partly have 
escaped regularization. The fact that dare with future meaning is virtually always telic $\{20\}$ may have played a role; other verbs like ire 'to go' are either atelic or telic, depending on their complements. What is perhaps equally important is the high frequency of the verb dare, which must have helped in preserving archaic patterns.

\subsection{Diachronic differences}

Differences in usage between Plautus and Terence can be explained in several ways. As both writers have the same subject matter, most phenomena found in only one of them are due to different stylistic preferences or diachronic changes, and often it is difficult to decide between these two possibilities. If I am correct in saying that the present infinitive with future reference is not a colloquialism or otherwise marked for register, differences in tense between the two authors are unlikely to be mere differences of style between the more colloquial Plautus and the more formal Terence. If under these circumstances Plautus uses the present infinitive with future meaning more frequently than the future infinitive, while the opposite is true of Terence, this is probably the result of diachronic change.

Kühner \& Stegmann (1962) do not make any remarks on such diachronic differences between Plautus and Terence, but Hofmann \& Szantyr (1965: 358) have some statistics based on Leopold (1904: 33) and Sjögren (1906: 57).\{21\} However, these authors count all future infinitives and all present infinitives with future reference. But since the use of the present instead of the future infinitive is more or less restricted to telic AcIs, they are not comparing like with like. In order to see if there is a diachronic decline between Plautus and Terence, I only count telic future infinitives, but I also include the few atelic present infinitives with future reference: 
Table 6 around here

As can be seen from table 6, there is a real decline of the present infinitive with future reference between Plautus and Terence. Among the telic events, Plautus uses it in around 45\% of the cases, while Terence employs it in only about $33 \%$ of all tokens. $\{22\}$

\section{CONCLUSIONS}

The present infinitive can be used with future reference only if the AcI is telic. The reason for this seems to be diachronic. Most AcIs referring to the present are atelic, while among the AcIs with future reference the telic ones predominate. Before the future infinitives were created, the present infinitives were used for both present and future reference. When the unambiguous future infinitives began to be employed instead of the present infinitives, they replaced the atelic present infinitives with future meaning first. Since most atelic infinitives have present reference, atelic present infinitives with future reference would be likely to be misinterpreted as having present reference. What is more, the distinction between simultaneity and posteriority is easier to draw among telic events than among atelic ones.

The second restriction is not an absolute one: the present infinitive with future reference is far more likely to be used if it has the same subject as the superordinate verb than if there is a difference in subjects. If there is identity of subjects between superordinate verb and AcI, the two events are more closely linked than is the case otherwise, and crosslinguistically such a close connection tends to be associated with fewer tense choices.

Sjögren's statement (1906: 57 and 59) that dare is particularly frequent among the present infinitives with future reference is correct. There are two reasons for this: first, forms 
of dare with future meaning are virtually always telic, and second, dare is a frequent verb and could therefore retain the old pattern better.

Finally, as was correctly observed by Hofmann \& Szantyr (1965: 358), there is a decline of the present infinitive with future meaning between Plautus and Terence.

The main purpose of this paper was to present new factual findings. However, I hope that it has done more than that: I would be happy if my readers were to draw the more general conclusion that various concepts of modern linguistics - telicity being only one of them - can shed light on old problems and help us to find the rationale behind seemingly random variation.

Wolfgang David Cirilo de Melo

All Souls College

High Street

University of Oxford

Oxford OXI 4AL

United Kingdom

email:wolfgang.demelo@all-souls.ox.ac.uk 


\section{NOTES}

$\{1\}$ This paper was presented on the $13^{\text {th }}$ International Colloquium on Latin Linguistics in Brussels in 2005. I am publishing it here rather than in the conference proceedings because of its length. I would like to thank Scott DeLancey for helpful discussions and my four anonymous referees for their useful comments. I would also like to thank Sally Chingyi Kung for her support; this article is dedicated to her.

\{2\} Cf. Pinkster (1990: 57-8 and 126-30) and Bolkestein (1976 and 1979) for problems associated with the AcI in Latin, and Dik (1997: ii.145-54) for a treatment of AcIs within a Functional Grammar framework. For the diachronic side cf. Lühr (1993: 242) and Hettrich (1997: 226).

\{3\} Note that infinitives, unlike finite verb forms, can only express relative, not absolute time. In what follows, I shall employ the traditional terminology and speak of 'present' and 'future' infinitives; 'simultaneous' and 'posterior' would be more precise, but also more opaque. I shall also say 'present' and 'future' rather than 'simultaneous' and 'posterior' meaning. Note, too, that the imperfect normally results in a present rather than a past infinitive because the imperfect, though a past tense, expresses simultaneity, a meaning which the past infinitive does not have.

\{4\} If there is no accusative, it may be strange to speak of an accusatiuus cum infinitiuo. I have retained the term AcI in order not to complicate matters.

\{5\} The term is used in Sanskrit grammars to refer to co-ordinated structures in which the first element is marked for tense, while the second is in the atemporal injunctive and gets the same temporal interpretation as the first. The Latin example is of course different in one crucial respect: we are dealing with two separate sentences spoken by two consecutive speakers.

\{6\} Examples from early tragedy and epic are Trag. inc. 61 (esse) or Enn. ann. 133 (decernere). Dari in Pacuu. trag. 167 is in an NcI. 
\{7\} Throughout this article I ignore infinitives ending in-assere. As I argue elsewhere (de Melo 2004: i.256-8 and de Melo forthcoming), the attestations are so scanty that it must remain unclear if they should be treated as future or present infinitives.

\{8\} I left out аппио. It is in Bennett's list and bears some relation to the uerba dicendi, but has no relevant material in Terence and is not even attested in Plautus.

$\{9\}$ The data for this article are collected in de Melo (2004: ii.142-78).

$\{10\}$ It is for instance discussed in Dik (1997: i.108-11). Dik's book also contains a number of tests that help to distinguish between telic and atelic events. Other semantic parameters, such as dynamic and non-dynamic, or momentaneous and non-momentaneous, do not matter here. Note that telicity entails that an event is also dynamic.

\{11\} A t-test shows that the likelihood that this pattern is statistically significant is higher than $99.95 \%$.

$\{12\}$ Even if hoc anno does not only modify the second AcI, its function can hardly be to specify an endpoint.

\{13\} The likelihood that this finding is statistically significant is higher than $99.95 \%$, as can be shown by a t-test.

$\{14\}$ The traditional view is that Indo-European did not have infinitives. It was challenged by Rix (1976), but García Ramón (1993) demonstrated that Rix’s position is untenable.

$\{15\}$ The existence of Proto-Italic is sometimes still disputed. The similarities between Latin (with Faliscan) on the one hand and Oscan and Umbrian on the other are of course partly due to borrowing. However, some of the features these languages share are more easily explained if we assume a common ancestor, Proto-Italic, than if we restrict ourselves to borrowing, see Meiser 1993: 170-1. We need both, the family tree model and the wave theory (Rix 1994: 28). \{16\} The traditional view about forms like dicere (Leumann 1977: 580-1 or Meiser 1998: 225 ) is that they are derived from locatives of verbal nouns in $*_{-}$es-. A different explanation 
(aorist $*_{-s-}$ and a dative variant $*_{-i}$ ) can be found in Blümel (1979: 79-81). Oscan deicum goes back to an accusative.

$\{17\}$ For the future passive infinitive cf. Coleman (1985: 211-12). For the future active infinitive cf. Postgate (1894 and 1904), Leumann (1977: 316 and 618), and Blümel (1979: 104-6).

\{18\} At the end of this discussion it should at least be pointed out that the future infinitive fore is, from a morphological perspective, a present infinitive. The grammaticalization of fore as a future infinitive seems to have to do with the fact that the root $* b^{h} u H_{x^{-}}$'become' is telic.

\{19\} A t-test shows that the likelihood that this pattern is statistically significant is higher than $99.95 \%$.

$\{20\}$ The infinitive is atelic only three times. One of the examples is dixit sese operam promissam dare (Plaut. Asin. 366), 'he said he would devote his attention to it as promised'. Here the action is considered as a continuous process rather than as something with a clearly definable end. The other two examples, Plaut. Trin. 5 and Plaut. Haut. 501, also involve the idiom operam dare / daturum. Outside this idiom, the verb does not have to be telic; iterative events like 'give books' are atelic. (This type seems to be rare.)

$\{21\}$ Leopold's dissertation contains the future infinitives, but not the present infinitives with future meaning, the data for which can be found in Sjögren.

$\{22\}$ As a t-test shows, the likelihood that this finding is statistically significant is between $90 \%$ and $95 \%$. 


\section{REFERENCES}

AdAms, J. N., 1977. The Vulgar Latin of the Letters of Claudius Terentianus (P. Mich. VIII, 467-72), Manchester: Manchester University Press.

Bennett, Charles E., 1910. Syntax of Early Latin, vol. 1, Boston: Allyn \& Bacon.

BlÜMEL, WOLFGANG, 1979. 'Zur historischen Morphosyntax der Verbalabstrakta im Lateinischen', Glotta 57, 77--125.

Bolkestein, A. MACHTELT, 1976. 'The relation between form and meaning of Latin subordinate clauses governed by verba dicendi', Mnemosyne 29, 155--75 and 268--300.

Bolkestein, A. MAChtelt, 1979. 'Subject-to-Object Raising in Latin?', Lingua 48, 15-34.

COLEMAN, RoBerT, 1985. 'The Latin future passive infinitive', Glotta 63, 208-12.

De Melo, Wolfgang D. C., 2004. Traces of an Earlier Verbal System in Archaic Latin: The Meaning and Usage of the Types faxō / faxim / impetrāssere, duim, and attigās, D.Phil. dissertation, 2 vols., University of Oxford.

De Melo, Wolfgang D. C., forthcoming. The Early Latin Verb System: Archaic Forms in Plautus, Terence, and Beyond, Oxford: Oxford University Press. 
DIK, SIMON C., 1997. The Theory of Functional Grammar, $2^{\text {nd }}$ edn., 2 vols., Berlin and New York: Mouton de Gruyter.

GARCÍA RAMÓN, JosÉ L., 1993. 'Zur Morphosyntax der passivischen Infinitive im OskischUmbrischen: u. $-f(e) i$, o. -fir und ursabellisch $*_{-f i e}\left(*_{-} d^{h} i e h_{1}\right)$ ', in Helmut Rix (ed.), OskischUmbrisch: Texte und Grammatik, Arbeitstagung der Indogermanischen Gesellschaft und der Società Italiana di Glottologia vom 25. bis 28. September 1991 in Freiburg, Wiesbaden: Ludwig Reichert, 106--24.

Givón, Talmy, 2001. Syntax: An Introduction, vol. 2, Amsterdam and Philadelphia: John Benjamins.

HETTRICH, HEINRICH, 1997. 'Syntaktische Rekonstruktion bei Delbrück und heute: nochmals zum lateinischen und griechischen AcI', in Emilio Crespo \& José L. García Ramón (eds.), Berthold Delbrück y la sintaxis indoeuropea hoy: Actas del Coloquio de la Indogermanische Gesellschaft, Madrid, 21-24 de septiembre de 1994, Madrid and Wiesbaden: Ludwig Reichert, 219-38.

Hofmann, Johann B. \& Szantyr, Anton, 1965. Lateinische Syntax und Stilistik, Munich: Beck.

Kalb, Wilhelm, 1888. Das Juristenlatein: Versuch einer Charakteristik auf der Grundlage der Digesten, 2nd edn., Nuremberg: Sebald. 
KÜHNER, RAPHAEL \& Stegmann, CARL 1962. Ausführliche Grammatik der lateinischen Sprache, 4th edn. (revised by A. Thierfelder), vol. 1, Darmstadt: Wissenschaftliche Buchgesellschaft.

LEOPOLD, JAN H., 1904. Quid Postgatius de origine Latini infinitivi et participii futuri activi senserit, Ph.D. dissertation, Leeuwarden: van Belkum.

Leumann, MANu, 1977. Lateinische Laut- und Formenlehre, 6th edn., Munich: Beck.

LÜHR, ROSEMARIE, 1993. 'Zur Umstrukturierung von agenshaltigen Sachverhaltsbeschreibungen in Komplementfunktion: dargestellt an altindogermanischen Sprachen', Historische Sprachforschung 106, 232-61.

MEISER, GERHARD, 1993. 'Uritalische Modussyntax: zur Genese des Konjunktiv Imperfekt', in Helmut Rix (ed.), Oskisch-Umbrisch: Texte und Grammatik; Arbeitstagung der Indogermanischen Gesellschaft und der Società Italiana di Glottologia vom 25. bis 28. September 1991 in Freiburg. Wiesbaden: Reichert, 167-195.

MEISER, GERHARD, 1998. Historische Laut- und Formenlehre der lateinischen Sprache, Darmstadt: Wissenschaftliche Buchgesellschaft.

PINKSTER, HARM, 1990. Latin Syntax and Semantics, London: Routledge.

PINKSTER, HARM, 1998. 'Is the Latin present tense the unmarked, neutral tense in the system?', in Rodie Risselada (ed.), Latin in Use: Amsterdam Studies in the Pragmatics of Latin, Amsterdam: Gieben, 63-83. 
Postgate, John P., 1894. 'The future infinitive active in Latin', Indogermanische Forschungen 4, 252-8.

Postgate, John P., 1904. 'The Latin future infinitive (crambe repetita)', Classical Review $18,450-6$.

RiX, Helmut, 1976. 'Die umbrischen Infinitive auf $-f i$ und die urindogermanische Infinitivendung - $d^{h} i \bar{o} i$, , in Anna E. Morpurgo Davies \& Wolfgang Meid (eds.), Studies in Greek, Italic, and Indo-European Linguistics Offered to Leonard A. Palmer on the Occasion of his Seventieth Birthday June 5, 1976, Innsbruck: Innsbrucker Beiträge zur Sprachwissenschaft, 319-31.

RiX, Helmut, 1994. 'Latein und Sabellisch: Stammbaum und / oder Sprachbund?', Incontri linguistici 17, 13-29.

SJÖGREN, HÅKAN, 1906. Zum Gebrauch des Futurums im Altlateinischen, Uppsala and Leipzig: Lundström and Harrassowitz. 
Table 1: AcIs with present and future reference - telic and atelic events

Telic Atelic Total \% of atelic AcIs

Pres. inf., pres. ref.

$\begin{array}{llll}85 & 637 & 722 & 88.23\end{array}$

Fut. + pres. inf., fut. ref. $\quad 185 \quad 104 \quad 289 \quad 35.99$

Total

$\begin{array}{llll}270 & 741 & 1011 & 73.29\end{array}$ 
Table 2: AcIs with future reference - telic and atelic events

Telic Atelic Total \% of atelic AcIs

$\begin{array}{lllll}\text { Fut. inf. } & 111 & 98 & 209 & 46.89\end{array}$

$\begin{array}{lllll}\text { Pres. inf., fut. ref. } & 74 & 6 & 80 & 7.5\end{array}$

$\begin{array}{lllll}\text { Total } & 185 & 104 & 289 & 35.99\end{array}$ 
Table 3: Telicity, time reference, and frequency in pre-Latin infinitivals

Telic Atelic

Pres. ref. rare frequent

Fut. ref. frequent very rare 
Table 4: Tenses and the subjects of the infinitives

Fut. inf. Pres. inf., fut. ref. Total $\%$ of pres. inf.

Same subj.

65

62

$127 \quad 48.82$

Different subj.

144

18

$162 \quad 11.11$ 
Table 5: Dare - infinitives with future reference

Fut. inf. Pres. inf., fut. ref. Total $\%$ of pres. inf.

Same subj.

13

25

$38 \quad 65.79$

Different subj.

7

8

$15 \quad 53.33$

Total

20

33

$53 \quad 62.26$ 
Table 6: The diachronic decline of the present infinitive with future reference

Fut. inf. Pres. inf., fut. ref. Total $\%$ of pres. inf., fut. ref.

$\begin{array}{lllll}\text { Plautus } & 76 & 63 & 139 & 45.32\end{array}$

$\begin{array}{lllll}\text { Terence } & 35 & 17 & 52 & 32.69\end{array}$ 